\title{
Review
}

\section{Is a History of Type 1 Allergic Diseases Associated with the Risk of Developing Multiple Sclerosis?}

\author{
Abdulrahman Alfawzan ${ }^{1, *},\left(\mathbb{D}\right.$, Saeed Alshahrani ${ }^{1}$, Ahmad Alswaidan $^{1}$, Ala Alkharaan ${ }^{1}$, \\ Hayyaf Aldossary ${ }^{2}$, Awad Almuklass ${ }^{2}$ \\ ${ }^{1}$ College of Medicine, King Saud bin Abdulaziz University for Health Sciences, Riyadh, Saudi Arabia \\ ${ }^{2}$ College of Medicine, King Saud bin Abdulaziz University for Health Sciences, Riyadh, Saudi Arabia; King Abdullah International \\ Medical Research Center (KAIMRC), Riyadh, Saudi Arabia
}

\section{ARTICLE INFO}

\section{Article History}

Received 25 October 2020

Accepted 31 January 2021

\section{Keywords}

Multiple sclerosis

allergy type 1

hypersensitivity

atopy

allergic diseases

\begin{abstract}
Multiple Sclerosis (MS) is an autoimmune disorder affecting the central nervous system, characterized by demyelination of the neurons with limited remyelination. There has been a rising trend toward associating a history of allergy with MS. Both MS and type 1 allergies are developed by a hyper-reactive immune system. This is further reinforced by the similar environmental and genetic factors of both diseases. This review examines the association between a history of type 1 allergic diseases and the risk of MS, as well as the influence of study location on the association. A literature search was conducted through the Saudi Digital Library search engine, which includes many databases, such as PubMed and Web of Science; articles addressing the relationship between MS and type 1 allergies were retrieved. In this review, most studies show an inverse or no association between type 1 allergy history and MS. Most articles concluded that the relationship is not statistically significant. One study stated that asthma increases MS risk. Geographical location does not influence MS and allergy association.
\end{abstract}

(C) 2021 Dr. Sulaiman Al Habib Medical Group. Publishing services by Atlantis Press International B.V. This is an open access article distributed under the CC BY-NC 4.0 license (http://creativecommons.org/licenses/by-nc/4.0/).

\section{INTRODUCTION}

Multiple Sclerosis (MS) is an autoimmune disorder affecting the central nervous system, characterized by demyelination of the neurons with limited remyelination [1]. MS occurs when the immune system loses one of its unique features, self-tolerance, leading it to mistakenly attack the body's cells and tissues [1]. Development of tolerance arises in through the central and peripheral immune systems. In central tolerance, the thymus and bone marrow participate in the early differentiation of $\mathrm{T}$ and $\mathrm{B}$ cells, respectively. The cells then leave the central sites, and peripheral tolerance ensures that any remaining self-reactive cells do not cause autoimmune disease [2]. Unfortunately, autoimmune diseases reflect a loss of self-tolerance arising from molecular mimicry, especially after infection $[3,4]$. Another explanation is epitope spreading, which occurs when self-epitopes are hidden from the immune system, manifested clinically as a relapsing-remitting course like MS $[5,6]$. When naïve $\mathrm{T}$ helper cells lose their self-tolerance, they react to the myelin sheath to develop T Helper 1 (Th1) cells, which produce cytokines, such as tumor necrosis factor-alpha, Interleukin 1 (IL-1), and IL6, which trigger more $\mathrm{T}$ cells, macrophages, and Immunoglobulin $\mathrm{E}$ (IgE) antibodies from B cells, causing demyelination of the myelin sheath $[7,8]$. In hypersensitivity type 1 , Th2 cells respond to an

“Corresponding author. Email: alfawzan.job@gmail.com

Peer review under responsibility of the Dr. Sulaiman Al Habib Medical Group originally harmless substance, leading to the production of IgE antibodies, which bind to different antigens, such as dust, food, and pollen, promoting the release and production of proinflammatory mediators and causing the clinical signs and symptoms of allergies [9]. Along with genetic and environmental factors, both MS and allergies are developed by a hyperreactive immune system involving T helper cells.

The relationship between MS and allergies has been tested in many studies, which have concluded that the history of allergies is inversely related to MS risk, and that Th2 allergic cells are protective against MS [10]. Furthermore, low exposure to microbes in childhood increases the risk of developing a hyperreactive immune system for both MS and allergies later [11,12].

The prevalence of MS diagnoses has increased worldwide because of the growing awareness of the disease, its signs, and symptoms, as well as improving diagnostic capability, leading to increased life expectancy. Geographically, MS incidence is higher near the north and south latitudes, which could be attributed to more sophisticated healthcare systems in those areas $[13,14]$. The prevalence in Saudi Arabia is 25 out of 100,000 , which is relatively low $[14,15]$. Other factors associated with increased risk of MS include smoking [16], vitamin D deficiency [17], and viral infections (e.g., EpsteinBarr virus) [18]. Interestingly, there is a $2-4 \%$ risk of developing MS among siblings, 5\% risk among dizygotic twins, and 30\% among monozygotic twins [19]. 
Although MS is a common, disabling disease, minimal data have been collected to study the association between type 1 allergies and MS. Therefore, a literature search was conducted through the Saudi Digital Library search engine, which includes many databases, such as PubMed and Web of Science; articles addressing the relationship between MS and type 1 allergies were retrieved. This short review assesses the association between the history of allergic diseases type 1 and the risk of MS. It will also determine the influence of the geographical locations of studies on the nature of the association.

\section{MATERIALS AND METHODS}

We collected all articles addressing the relationship between MS and type 1 allergies. Articles were retrieved from the Saudi Digital Library and the Google Scholar database. Keywords used in the search engines were Multiple Sclerosis, Allergy, Hypersensitivity, Atopy, and Allergic Diseases. All articles addressing the relationship between MS and type 1 allergies were included. Select articles from the bibliographies were added. Limitations included (1) studies not written in English, (2) conference articles, and (3) unpublished articles. Thirty-three articles were initially retrieved, but with the literature review exclusion criteria, only 15 articles were incorporated. We read each article thoroughly prior to summarizing its salient points in a Word document. Then, we extracted the data into a table. The table shows the journal's impact factor and the study's name, design, location, inclusion and exclusion criteria, sample size, statistical tests, severity of allergy, types of MS, conclusion, and limitations. No statistical program was used. We excluded articles published in nonindexed journals, articles addressing the association of type 1 allergies with other autoimmune diseases, and articles whose study design had no comparison groups.

\section{RESULTS}

Although one study suggested the possibility of a risk association, six concluded that allergies tend to be inversely associated with MS, and 11 studies indicated no association between allergies and MS. The Odds Ratios (ORs) are shown in Table 1. The asthma OR was associated with a higher risk of developing MS in Australia [20]. Four studies in the UK [21], the USA [22], a meta-analysis [23], and France [24] showed no risk of MS among asthma patients. Two studies in Italy $[25,26]$ concluded that asthma tends to be protective against developing MS. Moreover, respiratory allergies, including asthma and allergic rhinitis, showed an inverse association with MS

Table 1 Odds ratio between multiple sclerosis and different types of allergy

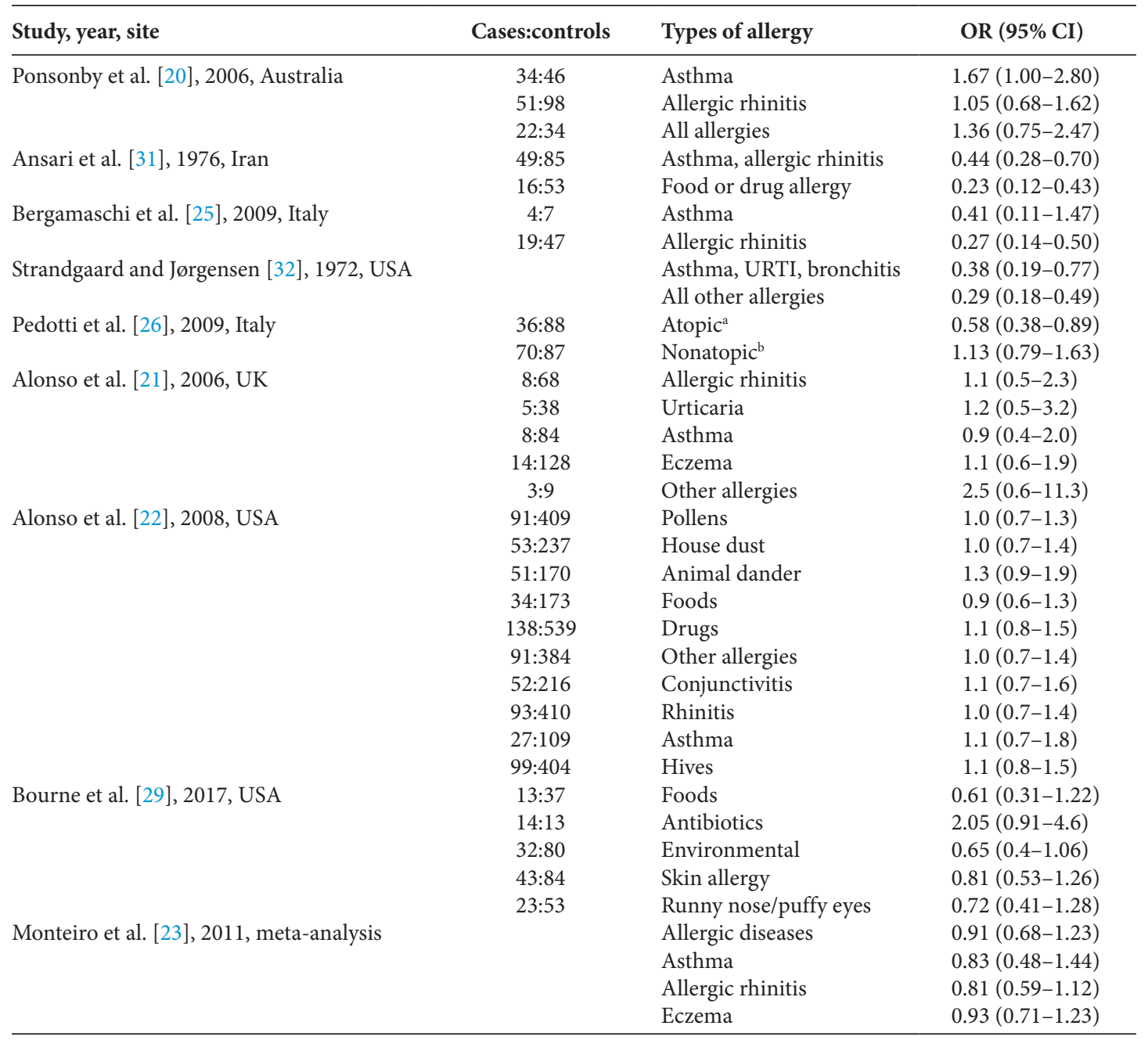

${ }^{a}$ Atopic: asthma, rhinitis, conjunctivitis, atopic eczema/dermatitis syndrome, or food allergy with respiratory allergies. ${ }^{\mathrm{b} N o n a t o p i c: ~ c o n t a c t ~ d e r m a-~}$ titis, insect bites, medications, or food allergy without respiratory allergies. CI, confidence interval; URTI, upper respiratory tract infections. 
in USA, Iran, and Italy [26-28]. Whereas allergic rhinitis showed an inverse association in Iran [27] and Italy [25], no relationship was found in Australia [20], the UK [21], the USA [22], or in a metaanalysis [23]. In two US studies [22,29], a history of food and drug allergies [22] showed no MS risk relation, but in Iran [27], a food or drug allergy history showed an inverse association. Four studies $[21,23,26,29]$ evaluated the risk of developing MS in patients with a history of skin allergies such as urticaria and eczema. None of the studies found a relation.

Six studies in France [24], Italy [25], Northern Italy [26], Iran [27], and the USA $[28,29]$ showed an inverse association between type 1 allergies and MS (Table 2). Respiratory allergy prevalence was significantly low in MS patients in Iran [27], Italy [25], the USA [28], and Northern Italy [26]. Females with respiratory allergies tend to have less risk of developing MS than do males in France $(p=0.001)$ [24]. However, a case-control study (including females only) in the USA [22] concluded that there was no relationship between MS and allergies such as allergic rhinitis and asthma.

Table 3 presents the data, method, results, and limitations of 11 studies that found no relationship between MS and allergies [21-23, 26,28-34]. A large Canadian population-based cohort with 6638 MS participants and 2509 controls was conducted to investigate the relationship between MS and cow milk allergies [34]. No association was found between MS and cow milk allergies during the perinatal period (males, $p=0.83$; females, $p=0.61$ ), early childhood (males, $p=0.3$; females, $p=0.82$ ), or late childhood (males, $p=0.51$; females, $p=0.32$ ). The geographical distribution showed no trends relating allergies and MS.

\section{DISCUSSION}

We aimed to investigate the association between MS and type 1 allergy histories. Most studies addressed an inverse or nonstatistically significant association between type 1 allergy histories and MS.

Hygiene theory has been linked to many autoimmune diseases and allergies, including MS and asthma, emphasizing that early childhood exposure to infections can protect against subsequent autoimmune illnesses [35]. The theory also explains the increased modern prevalence of both disorders, but it has never been proven. Also, one $\mathrm{T}$ cell lineage produces IL-17, which induces both allergic inflammation and MS [36-38]. The results of many studies that confirmed the risk association between allergies and MS may have been biased owing to less sophisticated healthcare systems in the past, underdiagnosed allergies in rural populations, and frequent diagnosis of MS patients because of frequent hospital visits with symptoms.

Six studies (Table 2) showed an inverse association between allergies and MS. Th2 cells, which are responsible for type 1 allergies, secrete IL-4, IL-5, and IL-10, which protect against the autoimmunity damage caused by the Th1 cells responsible for MS. With regard to asthma, there are two types, nonatopic (nonallergic) and atopic

Table 2 Data of case-control studies finding an inverse relation between allergy and MS

\begin{tabular}{|c|c|c|c|c|}
\hline Study, year, site & Sample size & Allergy type & Results & Notes \\
\hline $\begin{array}{l}\text { Sahraian et al. [27], } \\
\text { 2013, Iran }\end{array}$ & $195: 195$ & $\begin{array}{l}\text { (3) Food or drug allergy (FDA) and } \\
\text { nonspecific agent (including dust, } \\
\text { animal dander) }\end{array}$ & $\begin{array}{l}\text { History of allergy and MS } \\
\quad(p=0.04) \\
\text { RTA }(\mathrm{OR}=0.43 ; 95 \% \mathrm{CI} \\
0.28-0.66 ; p<0.001) \\
\text { FDA }(\mathrm{OR}=0.24 ; 95 \% \mathrm{CI} \\
0.13-0.43 ; p<0.001)\end{array}$ & $\begin{array}{l}80 \% \text { female participants. } \\
\text { Prevalence of asthma 1:9, } \\
\text { allergic rhinitis } 49: 84 \\
\text { No OR of other allergies }\end{array}$ \\
\hline $\begin{array}{l}\text { Neukirch et al. [24], 1997, } \\
\text { Paris and Toulouse }\end{array}$ & $\begin{array}{l}\text { Paris } 302: 3152 \\
\text { Toulouse } 308: 3774\end{array}$ & Asthma and nasal allergies & $\begin{array}{l}\text { Paris results } \\
\text { Nasal allergies, } p=0.006 \\
\text { Females only } \\
\text { (1) Asthma, } p=0.05 \\
\text { (2) Nasal allergy, } p=0.001 \\
\text { In Toulouse, association not } \\
\text { statistically significant }\end{array}$ & $\begin{array}{l}\text { Did not show Toulouse } \\
\text { results }\end{array}$ \\
\hline $\begin{array}{l}\text { Ren et al. [28], } \\
\text { 2017, }{ }^{\text {a }} \text { USA }\end{array}$ & $829: 2441$ & $\begin{array}{l}\text { Respiratory tract allergies: asthma, } \\
\text { URTI, and bronchitis }\end{array}$ & $\begin{array}{l}p=0.039(\mathrm{OR}=0.38 \\
0.19,0.77)\end{array}$ & \\
\hline $\begin{array}{l}\text { Bergamaschi et al. [25], } \\
\text { 2009, Italy }\end{array}$ & $200: 200$ & $\begin{array}{l}\text { (1) At least one allergic respiratory } \\
\text { disease (ARD) } \\
\text { (2) Asthma } \\
\text { (3) Allergic rhinitis }\end{array}$ & $\begin{array}{l}\text { ARDs }(\mathrm{OR}=0.33, p>0.001) \\
\text { Allergic rhinitis }(\mathrm{OR}=0.27 \\
\quad p>0.001) \\
\text { Asthma }(\mathrm{OR}=0.41, p<0.169)\end{array}$ & $\begin{array}{l}\text { Asthma cases }=4 \\
\text { control }=7\end{array}$ \\
\hline $\begin{array}{l}\text { Pedotti et al. [26], 2009, } \\
\text { Northern Italy }\end{array}$ & $423: 643$ & $\begin{array}{l}\text { Asthma, rhinitis, conjunctivitis, atopic } \\
\text { eczema/dermatitis syndrome, or (food } \\
\text { allergy with respiratory allergies) }\end{array}$ & $p=0.017$ & \\
\hline $\begin{array}{l}\text { Bourne et al. [29], } \\
\text { 2017, }{ }^{\text {a }} \text { USA }\end{array}$ & $418: 271$ & $\begin{array}{l}\text { Skin reaction (include rash and eczema), } \\
\text { nose or eyes reaction (include swollen } \\
\text { eyes and stuffy nose), gastrointestinal } \\
\text { reaction (including vomiting and } \\
\text { diarrhea) and anaphylactic shock }\end{array}$ & $\begin{array}{l}\text { MS relapse and food allergy, } \\
\qquad p=0.01\end{array}$ & \\
\hline
\end{tabular}

${ }^{a}$ These studies have results in Table 3. $\mathrm{CA}=$ urticaria, angioedema, eczema; $\mathrm{RTA}=$ asthma, allergic rhinitis. 
Table 3 Data of studies finding no relation between allergy and MS

\begin{tabular}{|c|c|c|c|c|}
\hline Study, year, site & Design & Sample size & Allergy type & $p+\mathrm{OR}$ \\
\hline $\begin{array}{l}\text { Ansari et al. [31], } \\
\text { 1976, USA }\end{array}$ & Cohort & $36: 40$ & $\begin{array}{l}\text { Asthma, hay fever or eczema, or } \\
\text { allergy to food, dust, dyes, contrast } \\
\text { material, or drugs }\end{array}$ & No results in manuscript \\
\hline $\begin{array}{l}\text { Ren et al. [28], } \\
\text { 2017, }{ }^{\text {a }} \text { USA }\end{array}$ & Case-control & $829: 2441$ & $\begin{array}{l}\text { Skin allergy, eye allergy, ear allergy, } \\
\text { and other unspecified allergies that } \\
\text { are not respiratory }\end{array}$ & $\begin{array}{l}p=0.281 \\
\mathrm{OR}=0.38 ; 0.19-0.77\end{array}$ \\
\hline $\begin{array}{l}\text { Strandgaard and Jørgensen } \\
\text { [32], 1972, Denmark }\end{array}$ & Cohort & $12: 12$ & Hypersensitivity reaction & No results in manuscript \\
\hline $\begin{array}{l}\text { Alonso et al. [21], } \\
\text { 2006, UK }\end{array}$ & Case-control & $163: 1523$ & $\begin{array}{l}\text { Allergic rhinitis, asthma, urticaria/ } \\
\text { angioedema, eczema, other allergic } \\
\text { conditions prior to the index date } \\
\text { (date of first Sx of MS) }\end{array}$ & OR $1.1 ; 0.8-1.6$ \\
\hline $\begin{array}{l}\text { Karimi et al. [33], } \\
\text { 2013, Iran }\end{array}$ & Case-control & $40: 40$ & $\begin{array}{l}\text { Any allergy manifested as rhinitis } \\
\text { conjunctivitis eczema, urticaria, or } \\
\text { asthma. Family history of allergy IgE } \\
\text { testing }\end{array}$ & $\begin{array}{l}p=1.00 \\
p=0.392 \text { higher EDSS and } \\
\quad \text { allergy in MS group } \\
p=0.776 \mathrm{MS} \text { initial symp- } \\
\text { toms and allergy }\end{array}$ \\
\hline $\begin{array}{l}\text { Alonso et al. [22], } \\
\text { 2008, USA }\end{array}$ & Case-control & $\begin{array}{l}\text { Primary: } 294: 1248 \\
\text { Secondary 248:248 } \\
\text { All participants females }\end{array}$ & $\begin{array}{l}\text { (1) Allergy to pollens, house dust, animal } \\
\text { dander, foods, drugs, and other } \\
\text { (2) Manifested as conjunctivitis, } \\
\text { rhinitis, asthma, hives, and other } \\
\text { manifestation }\end{array}$ & OR $1.0 ; 0.8-1.4$ \\
\hline $\begin{array}{l}\text { Ramagopalan et al. [34] } \\
\text { 2010, Canada }\end{array}$ & Cohort & 6638:2509 & $\begin{array}{l}\text { Cow milk allergy } \\
\text { Perinatal } \\
\text { Early childhood up to } 3 \text { years } \\
\text { Late childhood up to } 11 \text { years }\end{array}$ & $\begin{array}{l}\text { Perinatal: males } p=0.83 \\
\quad \text { females } p=0.61 \\
\text { Early childhood: males } \\
p=0.3 \text {, females } p=0.82 \\
\text { Late childhood: males } \\
p=0.51, \text { females } p=0.32\end{array}$ \\
\hline $\begin{array}{l}\text { Bourne et al. [29], } \\
\text { 2017, USA }\end{array}$ & Case-control & $418: 271$ & $\begin{array}{l}\text { Skin reaction (include rash and eczema), } \\
\text { Nose or eyes reaction (include swollen } \\
\text { eyes and stuffy nose), Gastrointestinal } \\
\text { reaction (include vomiting and } \\
\text { diarrhea) and Anaphylactic shock }\end{array}$ & $\begin{array}{l}\text { Age at onset of MS }(p=0.41) \\
\text { Sex }(p=0.30) \\
\text { Race }(p=0.06) \\
\text { Ethnicity }(p=0.54)\end{array}$ \\
\hline \multirow[t]{3}{*}{ Monteiro et al. [23], 2011} & \multirow[t]{3}{*}{$\begin{array}{l}\text { Systematic review } \\
\text { and meta-analysis }\end{array}$} & \multirow[t]{3}{*}{$2764: 262,620$} & $\begin{array}{l}\text { Allergic disease } \\
\text { Asthma }\end{array}$ & $\begin{array}{l}\text { Allergic diseases }(\mathrm{OR}=0.91 \text {; } \\
\quad 95 \% \mathrm{CI}, 0.68-1.23) \\
\text { Asthma }(\mathrm{OR}=0.83 ; 95 \% \mathrm{CI} \text {, }\end{array}$ \\
\hline & & & Allergic rhinitis & $\begin{array}{l}0.48-1.44) \\
\text { Allergic rhinitis }(\mathrm{OR}=0.81 \text {; } \\
\text { 95\% CI, 0.59-1.12) }\end{array}$ \\
\hline & & & Eczema & $\begin{array}{l}\text { Eczema }(\mathrm{OR}=0.93 ; 95 \% \mathrm{CI} \text {, } \\
0.71-1.23)\end{array}$ \\
\hline $\begin{array}{l}\text { Ashtari et al. [30], } \\
\text { 2013, Iran }\end{array}$ & Case-control & $48: 48$ & Cow milk allergy & \\
\hline $\begin{array}{l}\text { Pedotti et al. [26], 2009, } \\
\text { Northern Italy }\end{array}$ & $\begin{array}{l}\text { Population-based } \\
\text { case-control }\end{array}$ & $423: 643$ & $\begin{array}{l}\text { Contact dermatitis, insect bites, } \\
\text { medications, or food allergy } \\
\text { without respiratory allergies }\end{array}$ & $p=0.503$ \\
\hline
\end{tabular}

aThis study also has results in the inverse association table. EDSS, Expanded Disability Status Scale.

(allergic). Unfortunately, only one study distinguished between the two types and showed an inverse association [27]. Further studies, both longitudinal and experimental, should be conducted to investigate the relationship.

In this short review, the limitations are methodological or attributable to fundamental issues in the collected studies. Methodological limitations include publication bias and the exclusion of nonEnglish papers. With regard to the collected studies themselves, the limitations include the lack of diagnostic criteria for MS and allergies, the low sample size, and the failure to classify allergy severity or types of MS. Cofactors were also not mentioned, such as vitamin $\mathrm{D}$ deficiency, family history, ethnicity, and residence.
All studies included a comparison group that could hide genetic susceptibility, resulting in biased results. Thus, we recommend a further longitudinal, cohort study conducted only on people with MS. Also, there is a lack of studies corresponding to the severity and timing of allergic reactions or diseases with the clinical manifestations, course, and severity of MS.

\section{CONCLUSION}

Most studies in this review showed an inverse or a statistically nonsignificant association between type 1 allergy histories and MS. One study reported that asthma increased MS risk. Furthermore, 
geographical location has no influence on the relationship between MS and allergies.

\section{CONFLICTS OF INTEREST}

The authors declare they have no conflicts of interest.

\section{AUTHORS' CONTRIBUTION}

All authors have contributed to the manuscript and fulfilled the authorship criteria. A. Alfawzan, SA, A. Alswaidan and A. Alkharaan contributes effectively in data collection and writing the first and final draft of the study. HA and A. Almuklass were responsible for conception and design of the study, and provided critical revision of the article. All authors approved the final version to be submitted.

\section{REFERENCES}

[1] Ermann J, Fathman CG. Autoimmune diseases: genes, bugs and failed regulation. Nat Immunol 2001;2;759-61.

[2] Dendrou CA, Fugger L, Friese MA. Immunopathology of multiple sclerosis. Nat Rev Immunol 2015;15;545-58.

[3] Harkiolaki M, Holmes SL, Svendsen P, Gregersen JW, Jensen LT, McMahon R, et al. T cell-mediated autoimmune disease due to low-affinity crossreactivity to common microbial peptides. Immunity 2009;30;348-57.

[4] Münz C, Lünemann JD, Getts MT, Miller SD. Antiviral immune responses: triggers of or triggered by autoimmunity? Nat Rev Immunol 2009;9;246-58.

[5] McMahon EJ, Bailey SL, Castenada CV, Waldner H, Miller SD. Epitope spreading initiates in the CNS in two mouse models of multiple sclerosis. Nat Med 2005;11;335-9.

[6] Ji Q, Castelli L, Goverman JM. MHC class I-restricted myelin epitopes are cross-presented by Tip-DCs that promote determinant spreading to $\mathrm{CD}^{+} \mathrm{T}$ cells. Nat Immunol 2013;14; 254-61.

[7] Correale J, Gaitán MI, Ysrraelit MC, Fiol MP. Progressive multiple sclerosis: from pathogenic mechanisms to treatment. Brain 2017;140;527-46.

[8] Waldman A, Ghezzi A, Bar-Or A, Mikaeloff Y, Tardieu M, Banwell B. Multiple sclerosis in children: an update on clinical diagnosis, therapeutic strategies, and research. Lancet Neurol 2014;13;936-48.

[9] Bellanti JA. Genetics/epigenetics/allergy: the gun is loaded... but what pulls the trigger? Allergy Asthma Proc 2019;40;76-83.

[10] Del Prete G. Human Th1 and Th2 lymphocytes: their role in the pathophysiology of atopy. Allergy 1992;47;450-5.

[11] Bach JF. The effect of infections on susceptibility to autoimmune and allergic diseases. N Engl J Med 2002;347;911-20.

[12] Waubant E, Mowry EM, Krupp L, Chitnis T, Yeh EA, Kuntz N, et al. Common viruses associated with lower pediatric multiple sclerosis risk. Neurology 2011;76;1989-95.

[13] Koch-Henriksen N, Sørensen PS. The changing demographic pattern of multiple sclerosis epidemiology. Lancet Neurol 2010; 9;520-32.

[14] Heydarpour P, Khoshkish S, Abtahi S, Moradi-Lakeh M, Sahraian MA. Multiple sclerosis epidemiology in Middle East and North Africa: a systematic review and meta-analysis Neuroepidemiology 2015;44;232-44.

[15] Al Tahan AM, Alsharoqi I, Bohlega SA, Dahdaleh M, Daif A, Deleu D, et al. Characteristics of multiple sclerosis in the Middle East with special reference to the applicability of international guidelines to the region. Int J Neurosci 2014;124;635-41.

[16] Wingerchuk DM. Smoking: effects on multiple sclerosis susceptibility and disease progression. Ther Adv Neurol Disord 2012;5;13-22.

[17] Mowry EM, Waubant E, McCulloch CE, Okuda DT, Evangelista AA, Lincoln RR, et al. Vitamin D status predicts new brain magnetic resonance imaging activity in multiple sclerosis. Ann Neurol 2012;72;234-40.

[18] Jakimovski D, Ramanathan M, Weinstock-Guttman B, Bergsland N, Ramasamay DP, Carl E, et al. Higher EBV response is associated with more severe gray matter and lesion pathology in relapsing multiple sclerosis patients: a case-controlled magnetization transfer ratio study. Mult Scler J 2020;26;322-32.

[19] Vukusic S, Marignier R. Multiple sclerosis and pregnancy in the 'treatment era'. Nat Rev Neurol 2015;11;280-9.

[20] Ponsonby AL, Dwyer T, van der Mei I, Kemp A, Blizzard L, Taylor B, et al. Asthma onset prior to multiple sclerosis and the contribution of sibling exposure in early life. Clin Exp Immunol 2006;146;463-70.

[21] Alonso A, Jick SS, Hernán MA. Allergy, histamine 1 receptor blockers, and the risk of multiple sclerosis. Neurology 2006; $66 ; 572-5$.

[22] Alonso A, Hernán MA, Ascherio A. Allergy, family history of autoimmune diseases, and the risk of multiple sclerosis. Acta Neurol Scand 2008;117;15-20.

[23] Monteiro L, Souza-Machado A, Menezes C, Melo A. Association between allergies and multiple sclerosis: a systematic review and meta-analysis. Acta Neurol Scand 2011;123;1-7.

[24] Neukirch F, Lyon-Caen O, Clanet M, Bousquet J, Feingold J, Druet P. Asthma, nasal allergies, and multiple sclerosis. J Allergy Clin Immunol 1997;99;270-1.

[25] Bergamaschi R, VillaniS, Crabbio M, Ponzio M, Romani A, Verri A, et al. Inverse relationship between multiple sclerosis and allergic respiratory diseases. Neurol Sci 2009;30;115-18.

[26] Pedotti R, Farinotti M, Falcone C, Borgonovo L, Confalonieri P, Campanella A, et al. Allergy and multiple sclerosis: a populationbased case-control study. Mult Scler 2009;15;899-906.

[27] Sahraian MA, Jafarian S, Sheikhbahaei S, Safavi F. Respiratory tract rather than cutaneous atopic allergy inversely associate with multiple sclerosis: a case-control study. Clin Neurol Neurosurg $2013 ; 115 ; 2099-102$.

[28] Ren J, Ni H, Kim M, Cooley KL, Valenzuela RM, Asche CV. Allergies, antibiotics use, and multiple sclerosis. Curr Med Res Opin 2017;33;1451-6.

[29] Bourne T, Waltz M, Casper TC, Kavak K, Aaen G, Belman A, et al. Evaluating the association of allergies with multiple sclerosis susceptibility risk and disease activity in a pediatric population. J Neurol Sci 2017;375;371-5.

[30] Ashtari F, Jamshidi F, Shoormasti RS, Pourpak Z, Akbari M. Cow's milk allergy in multiple sclerosis patients. J Res Med Sci 2013;18;S62-S5.

[31] Ansari KA, Yokoyama MM, Rand A. Circulating IgE, allergy and multiple sclerosis. Serum levels of IgE, other immunoglobulins and complement $\left(\mathrm{C}_{3}^{\prime}\right)$ in patients with multiple sclerosis in exacerbation and other neurologic diseases. Acta Neurol Scand 1976;53;39-50. 
[32] Strandgaard S, Jørgensen PN. Delayed hypersensitivity to myelin antigen in multiple sclerosis investigated with the leucocyte migration method. Acta Neurol Scand 1972;48;243-8.

[33] Karimi P, Modarresi SZ, Sahraian MA, Shokouhi Shoormasti R, Mahlooji M, Kazemnejad A, et al. The relation of multiple sclerosis with allergy and atopy: a case control study. Iran J Allergy Asthma Immunol 2013;12;182-9.

[34] Ramagopalan SV, Dyment DA, Guimond C, Orton SM, Yee IM, Ebers GC, et al. Childhood cow's milk allergy and the risk of multiple sclerosis: a population based study. J Neurol Sci 2010;291;86-8.

[35] Asher MI, Montefort S, Björkstén B, Lai CKW, Strachan DP, Weiland SK, et al. Worldwide time trends in the prevalence of symptoms of asthma, allergic rhinoconjunctivitis, and eczema in childhood: ISAAC Phases One and Three repeat multicountry cross-sectional surveys. Lancet 2006;368;733-43.

[36] Molet SM, Hamid QA, Hamilos DL. IL-11 and IL-17 expression in nasal polyps: relationship to collagen deposition and suppression by intranasal fluticasone propionate. Laryngoscope 2010;113;1803-12.

[37] McFarland HF, Martin R. Multiple sclerosis: a complicated picture of autoimmunity. Nat Immunol 2007;8;913-19.

[38] Stock P, Lombardi V, Kohlrautz V, Akbari O. Induction of airway hyperreactivity by IL-25 is dependent on a subset of invariant NKT cells expressing IL-17RB. J Immunol 2009;182;5116-22. 